\title{
São João Quântico e o "arraiá" da Física Moderna: uma experiência didática no 3ำ ano do Ensino Médio
}

\author{
José de Sousa Leite 1 \\ ${ }^{1}$ Universidade Federal Sul e Sudeste do Pará (UNIFESSPA)
}

Palavras-Chave: ensino, aprendizagem e física moderna.

\section{Introdução}

O trabalho está pautado no protagonismo do aluno, inovação da dinâmica escolar do ensino de ciências e proposta progressista de inserção da Física Moderna na Educação Básica. Com isso, ressalta-se a evidente resistência ou exclusão da Física Quântica das propostas de ensino. Para tanto, a presente experiência didática visa dizer que a ciência do início do século XX (Max Planck e outros) precisa fazer parte da escola do século XXI.

O tema ora proposto é fruto do Mestrado Nacional Profissional de Ensino de Física (MPNEF) e tem como origem as provocações promovidas pelas disciplinas Marcos Teóricos da Física (prof. Dr. Erico Novais) e Mecânica Quântica (prof. Dr. Edney Granhen). Diz-se, nas rodas de conversas de professores que o ensino-aprendizagem deve partir dos conhecimentos prévios dos estudantes. Assim, permite-se concluir que a realidade e o cotidiano dos nossos discentes estão permeadas de Física Moderna. Portanto, existe uma grande gama fenômenos e perguntas que só poderão ser respondidas e compreendidas com a Teoria da Relatividade ou a Mecânica Quântica. Então, por que não introduzir esses saberes no ensino básico? Ou melhor, desde do ensino fundamental?

Dessa forma, buscou-se em parceria com a Universidade Federal Sul e Sudeste do Pará (Polo 29 - Marabá/PA) apoio para incluir os alunos da Escola Estadual Romildo Veloso e Silva (Ourilândia do Norte-PA) nessa nova realidade de se fazer ciência. É fantástico e significativo observar o brilho nos olhos dos alunos ao compreenderem o porquê das lâmpadas que iluminam as ruas da cidade ao ligarem e se apagarem sem um processo manual, simplesmente através do Efeito Fotoelétrico (Albert Einstein).

Por conseguinte, cabe dizer que dois projetos ganharam raízes e estão produzindo frutos no município de Ourilândia do Norte-Pará para os alunos do $1^{\circ}$ ao $3^{\circ}$ ano do Ensino Médio. São eles: A caminho da UNIFESSPA (Universidade Federal Sul e Sudeste do Pará) e São João Quântico: o "arraiá" da Física Moderna". O primeiro, resume-se na visitação e participação das mostras científicas da universidade e, o segundo, trata-se de um produto final da disciplina Mecânica Quântica. O segundo, consiste na proposição de uma transposição didática através de uma Mostra Científica para comunidade escolar dos conteúdos Teoria da Relatividade Restrita, Elementos da Mecânica Quântica e os Desafios da Física no século XXI (partículas subatômicas, atômicas e nanotecnologia).

Destaca-se, que a proposta inicial desse produto era realizar um Carnaval Quântico, mas como a culminância se deu no mês de junho (Festas Juninas/ São João), os alunos decidiram transformar o evento em uma festa São João "Quântico". Desta forma, a culminância do projeto ocorreu conforme as caracterizações das festas juninas locais (decoração e trajes). Uma forma de conectar a ciência com o cotidiano e atrair a atenção dos convidados. Por fim, a mostra foi um verdadeiro "arraiá" de São João (bandeirolas, conversas caipiras, fogueira artificial, comidas típicas, etc.).

\section{Metodologia e Material}

Trata-se de um produto final da disciplina Mecânica Quântica do Mestrado Nacional Profissional de Ensino de Física (MNPEF) visando testar, estabelecer e criar estratégias e pedagogias que auxiliem no processo de aprendizagem da ciência moderna na Educação Básica.

Assim sendo, conforme Nogueira (2011) se a missão da escola é formar o cidadão integral, parece decente, coerente e plausível planejar estratégias educacionais diferentes, inovadoras e significativas para ajudar nesse processo de formação.

Com isso, os trabalhos propostos se organizaram em cinco etapas ou sequências de ensino: 1) pesquisar os temas (Teoria da Relatividade Restrita - transformações de Galileu, relatividade do tempo, paradoxo dos gêmeos e relatividade do comprimento/ Elementos da Mecânica Quântica -

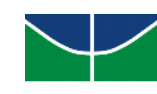


efeito fotoelétrico, radiação do corpo negro, modelo atômico de Bohr, dualidade onda-partícula e o princípio da incerteza de Heisenberg/ Desafios da Física no século XXI - partículas subatômicas e atômicas, bóson de Higgs e nanotecnologia) através da atividade "Para começo de conversa"; 2) expor os temas e realizar as atividades propostas do livro "Conexões com a Física" da Editora Moderna/ 3 ano Ensino Médio; 3) organizar as apresentações em trios (3 alunos) apresentando os principais conceitos por meio das seguintes ferramentas: fantoche, teatro, paródia, simulações, experimentos, contação de histórias, jogos, filmes ( $O$ menino que descobriu o vento/ $O$ nome da rosa/ Mutação/ Vingadores 4 "O ultimato"), etc; 4) realizar a culminância com apresentação dos trabalhos para as turmas do $1^{\circ}$ e $2^{\circ}$ ano da escola (por isso arraiá); 5) aplicar um questionário para análise e revisão do projeto aplicado.

\section{Resultados e discussões}

Para avaliação de resultados está previsto a aplicação de um questionário sobre as estratégias de aprendizagem, além da apresentação do produto final pelos alunos.

O que se pode adiantar em torno dos dados observados e das já etapas realizadas são: o reencantamento pelo ensino de física (Hugo Assman); o protagonismo dos estudantes (Assmann); a coceira nas ideias (Rubem Alves); a compreensão da bifurcação da ciência, ou seja, a física dos experimentos e dos modelos matemáticos (Resnick e Eisberg); o pensamento sistêmico (Edgar Morin); e fascinação pela física e o encontro da alegria na escola (Georges Snyders).

\section{Conclusões}

Faz-se os seguintes destaques e provocações a respeito da presente pesquisa experimental: a necessidade de promoção do protagonismo do aluno através dos "arraiais" ou "carnavais" quânticos; inserção e distribuição dos conteúdos da Física Moderna ao longo dos anos de estudo do Ensino Fundamental e Médio; a valorização da física experimental sob os modelos matemáticos; e a utilização da pedagogia da pergunta (papel do professor é perguntar) de Paulo Freire e a pedagogia da curiosidade (papel do professor é criar coceira nas ideias) de Rubem Alves como ferramentas de sedução, fascinação e encantamento pelo ensino de física.

\section{Agradecimentos}

À instituição Universidade Federal Sul e Sudeste do Pará (UNIFESSPA) pelo apoio e orientação a respeito da inscrição, meios e preparação do resumo. À Capes e Sociedade Brasileira de Física (SBF) pela promoção e apoio ao programa Mestrado Nacional Profissional de Ensino de Física (MPNEF). Ainda, ao coordenador do programa prof. Dr. Erico Novais e também, à minha esposa Lúcia Leite (Prof. Esp. em Língua Portuguesa) pela revisão textual.

\section{Referências}

ALVES, Rubem. A alegria de ensinar. 3를 Ed. Campinas: ARS POETICA EDITORA LTDA, 1994. , Rubem. $O$ desejo de ensinar e a arte de aprender. $1^{\mathfrak{a}}$ Ed. Campinas: Fundação Educar DPaschoal, 2004.

ASSMAN, Hugo. Reencantar a Educação: rumo à sociedade aprendente.5 $5^{\mathrm{a}}$ Ed. Rio de Janeiro: Vozes, 2000.

CARVALHO, Roberto Muniz Barreto de. Georges Snyders: em busca da alegria na escola.

Revista PERSPECTIVA. Florianopolis, v.17, n. 32., p.151-170 jul./dez. 1999; Acesso em:

07/06/2019; Disponível em:

https://periodicos.ufsc.br/index.php/perspectiva/article/download/10528/10074

EISBERG, Robert; RESNICK, Roberto. Física Quântica: átomos, moléculas, sólidos, núcleos e partículas. - Rio de Janeiro: Campus, 1979.

FREIRE, Paulo; FAUNDEZ, Antônio. Por um pedagogia da pergunta. $3^{\underline{a}}$ Ed. Rio de Janeiro: Paz e Terra, 1985.

MARTINI, Glorinha; e et al. Conexões com a física. 3ํㅡ. São Paulo: Moderna, 2016.

NOGUEIRA, Nilbo Ribeiro. Pedagogia de projetos: etapas, papéis e atores. $4^{\circ}$ ed. São Paulo:

Érica, 2008.

MORIN, Edgar. Os sete saberes necessários à educação do futuro. $8^{a}$ Ed. São Paulo: Cortez, 2003. 